\title{
Spatial and seasonal variation in reproductive indices of the clupeids Limnothrissa miodon and Stolothrissa tanganicae in the Congolese waters of northern Lake Tanganyika
}

\author{
Mulimbwa N'sibula T. 1,", Leona J.M. Milec ${ }^{2}$, Joost A.M. Raeymaekers ${ }^{2}$, \\ Jouko Sarvala ${ }^{3}$, Pierre-Denis Plisnier ${ }^{4}$, Béatrice Marwa ${ }^{5} \&$ \\ Jean-Claude Micha ${ }^{6,7}$ \\ ${ }^{1}$ Centre de Recherche en Hydrobiologie, Uvira, R.D. Congo, P.O. Box 73 Sud Kivu. \\ ${ }^{2}$ Faculty of Biosciences and Aquaculture, Nord University, N-8049 Bodø, Norway. \\ ${ }^{2}$ Hasselt University, Centre for Environmental Sciences, Research Group Zoology: Biodiversity \& \\ Toxicology, Agoralaan gebouw D, 3590 Diepenbeek, Belgium. \\ ${ }^{3}$ Department of Biology, University of Turku, Turku FI-20014, Finland. \\ ${ }^{4}$ University of Liège, Chemical Oceanography Unit, Institut de Physique (B5A), \\ B-4000 Liège, Belgium. \\ ${ }^{5}$ Regional Director of Fisheries \& Aquaculture, Lake Tanganyika Authority Secretariat (Burundi, D.R. \\ Congo, Tanzania \& Zambia) P.O Box 4910 Ngagara - Bujumbura, Republic of Burundi. \\ ${ }^{6}$ Ecole Regionale post-universitaire d'Aménagement et de gestion intégrés des Forêts Tropicales \\ (ERAIFT), UNIKIN, Kinshasa, DR Congo. \\ ${ }^{7}$ Namur University (UNamur) Namur, Belgium. \\ *Corresponding author: mulimbwa49@gmail.com
}

\begin{abstract}
Knowledge on the reproductive biology of the endemic clupeids Limnothrissa miodon and Stolothrissa tanganicae, two main target species of the pelagic fisheries of Lake Tanganyika, is constrained by fragmented monitoring activities. Here, we investigate the nursing areas of L. miodon, the timing of reproductive activities of littoral and pelagic L. miodon, and the timing of reproductive activities of pelagic $S$. tanganicae in the Congolese waters of the northern end of Lake Tanganyika (Bujumbura sub-basin). Nursing areas were determined year-round (2009-2010) based on the presence of clupeid larvae at two sandy and two stony beaches. The gonadosomatic index (GSI) and the proportion of fish having ripe gonads were used to study variation in reproductive indices in space (littoral vs. pelagic zones) during one year (2013-2014), as well as in time (dry vs. rainy season) during three years (2013-2016). Larvae of L. miodon were more frequently encountered on sandy than on stony beaches. Mature L. miodon females were more abundant in the littoral than in the pelagic zone, while the proportion of mature males in both habitats was similar. Irregular, low amplitude peaks could be distinguished in the GSI and proportion of mature males and females, but averages only differed between the dry and the rainy season in males. In contrast, GSI and proportions of mature males and females in $S$. tanganicae were higher in the dry season than in the rainy season. The reproductive effort of males and females of S. tanganicae and littoral L. miodon, but not pelagic L. miodon, was strongly synchronized. Interestingly, reproductive investment was also synchronised between pelagic male L. miodon, and pelagic S. tanganicae. Our time series strongly supports the view that L. miodon
\end{abstract}


reproduces year-round in the littoral zone, while reproduction in S. tanganicae is seasonal. For fisheries management, we recommend year-round protection of sandy beaches, which are the main breeding grounds for L. miodon.

Key words. Nursing areas, reproductive activity, clupeids, Lake Tanganyika, fisheries management.

Mulimbwa N'sibula T., Milec L.J.M., Raeymaekers J.A.M., Sarvala J., Plisnier P.-D., Marwa B. \& MICHA J.-C. (2022). Spatial and seasonal variation in reproductive indices of the clupeids Limnothrissa miodon and Stolothrissa tanganicae in the Congolese waters of northern Lake Tanganyika. Belgian Journal of Zoology 152: 13-31. https://doi.org/10.26496/bjz.2022.96

\section{Introduction}

Lake Tanganyika is the oldest of the East African Great Lakes (COULTER 1991) and is the second largest and deepest freshwater body in the world. Up to now, around 1200 species have been identified in this lake, classifying it as the second most diverse lake in the world (COHEN et al. 1993). Among the biota, the fishes show a high degree of biodiversity (VAN STEENBERGE et al. 2011). Whole-lake overviews report 240-250 cichlid species (95\% endemics) and 75 non-cichlid species (59\% endemics) (SNOEKS 2000; SAlzBURGer et al. 2014; RonCO et al. 2020). Lake Tanganyika is bordered by four countries (DR Congo, Burundi, Tanzania and Zambia; Figure 1). Bathymetric maps of the lake show seven subbasins with different depths (Bujumbura, Kalemie, East Marungu, Mpulungu, Moba, Kigoma and Rumonge) (TIERCELIN \& MONDEGUER 1991).

Lake Tanganyika fisheries are crucial for human nutrition in the riparian countries. A major part of the catch derives from the open waters of the lake, where two endemic freshwater clupeids Limnothrissa

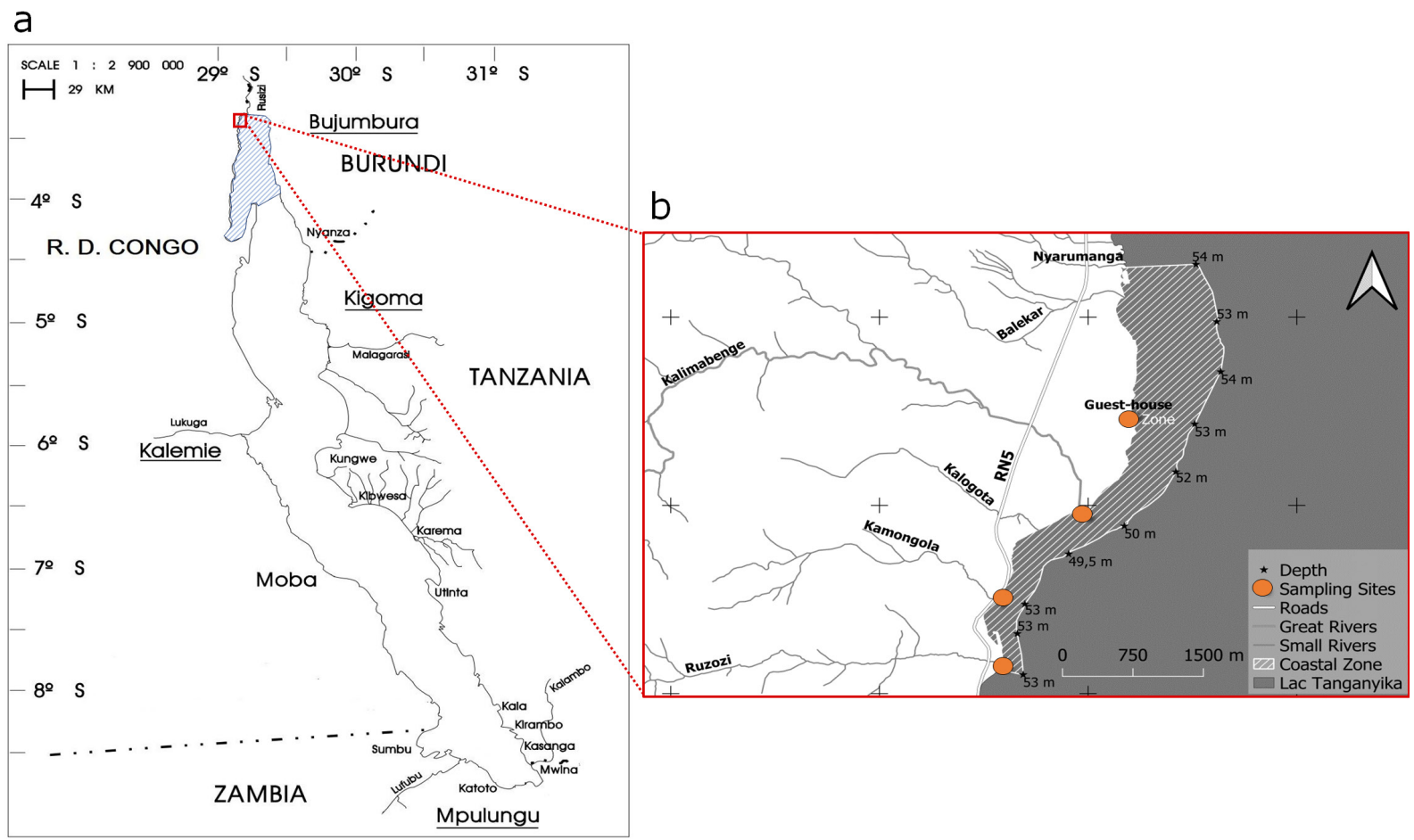

Figure 1 - (a) Geographic position of Lake Tanganyika bordered by DR Congo, Burundi, Tanzania and Zambia. The shaded area marks the Bujumbura sub-basin. (b) Inset map of the region of Uvira, marking the position of the four littoral study sites sampled for clupeid larvae. 
miodon (Boulenger, 1906) and Stolothrissa tanganicae Regan, 1917 are the main target species. Both species comprise $60 \%$ of the total catch, and even more so in the northernmost part of the lake, the Bujumbura sub-basin (MöLSÄ et al. 1999; MulimBwA 2006). Clupeids are a diverse group of fish which are largely marine, such as Atlantic herring (Clupea harengus) and European sardine (Sardina pilchardus), but the group also has many brackish and freshwater representatives (LAVOUÉ et al. 2013). For instance, they are prominent in the pelagic zones of some large African lakes and reservoirs (WhiteHEAD 1985; Kolding et al. 2019). Examples include the genera Nannothrissa in Lake Maï Ndombe (MichA et al. 2018) or Pellonula in Lake Volta in western Africa (POLL 1974).

In Lake Tanganyika, the clupeids are caught in the pelagic area by artisanal fishers using lift-nets of 6-8 mm mesh sizes and artificial light during dark nights. The fishing pressure has steeply increased during the last decades (MÖLSÄ et al. 1999; SARVALA et al. 2006; VAN DER KNAAP et al. 2014), arousing concerns about the sustainability of the fishery (DE KEYZER et al. 2020). Recently, efforts have been made to elucidate the stock (population) structure of the Tanganyika sardines using genetic, genomic and parasitological data. While $S$. tanganicae shows no or only a weak pattern of isolation by distance, implying a single, near-panmictic population, L. miodon seems to harbor structural genomic variation along the North-South axis (DE KEYZER et al. 2019; JUNKER et al. 2020; KMÉNTOVA et al. 2020). Both species appear to have strong sex differentiation, which involves different genomic regions in each species (JUNKER et al. 2020). This may reflect the different reproductive biology of the two species. In this situation, knowledge on the reproductive activities, spawning grounds, and nursing areas is urgently needed. For the purpose of this study, 'reproductive activities' refers to all spawning behaviour, i.e., migration to spawning grounds, release of eggs and sperm, and fertilization.

Published information of the breeding ecology of L. miodon in Tanganyika derives from different parts of the lake and from different times, resulting in patchy and incomplete, and even partly conflicting views. A comprehensive overview of its reproductive biology does not exist yet. In southern Lake Tanganyika, the spawning area of L. miodon is probably in the nearshore waters less than $130 \mathrm{~m}$ deep (MATTHES 1967). Big shoals of L. miodon larvae often appear close to the shore in the daytime in the beginning of June and July (COULTER 1970), and juveniles of 15-40 mm length are also observed there (PEARCE 1985). In the North, L. miodon larvae migrate toward sandy shores as they grow (TSHIBANGU \& KINOSHITA 1995), while adults of around $100 \mathrm{~mm}$ fork length are thought to migrate toward the pelagic zone in October-November at the onset of the rainy season. At this size, corresponding to the age of one year, L. miodon becomes mainly piscivorous, and HENDERSON (1967) suggested that its movement toward pelagic zone is associated with the movements of its main prey fish, $S$. tanganicae. There is a general consensus that the main spawning takes place during the rainy season between November and May (MATThes 1967; Ellis 1971; PearCe 1985; Coulter 1991; MulimbWA \& ShirakiHARA 1994), although juvenile fish occur throughout the year, and a peak of spawning has been recorded from August to October at the North end of the lake (ARO \& MANNINI 1995). This time of the year is characterized by a strong secondary upwelling enriching the surface water with nutrient-rich hypolimnion water (PLISNIER et al. 1999). Surface plankton blooms are sometimes observed in this period (SYMOENS 1955; COCQUYT et al. 2021).

Stolothrissa tanganicae spends most of its life in the pelagic zone where it spawns, too. The eggs sink and hatch after 24-36 h to a depth of 75-150 m, after which the larvae swim upward (MATTHES 1967). Yet, as for L. miodon, more detailed information on the breeding of S. tanganicae is based on a limited number of relatively short time series from different parts of the lake, and over various seasons. Several indicators of breeding have been used, including the maturity stage, gonadosomatic index (GSI), and occurrence of larvae, which sometimes give conflicting information. In the South, sexually mature fish have been found to occur throughout the year (ELLIS 1971), and individuals may spawn several times a year (COULTER 1961). In Zambia, spawning peaks as indicated by the proportion of ripe gonads were 
apparent in November-December and April-July (ELLIS 1971), i.e., in the beginning and at the end of rainy season as well as into the dry season. On the other hand, juvenile abundance in Zambia suggested a major annual spawning at the end of or right after the dry season, i.e., in August-December (COULTER 1970), and length frequencies of older fish indicated a peak in September (PEARCE 1985). However, presently, S. tanganicae appears only sporadically in the southern part of the lake (PLISNIER et al. 2009). A peak was observed in January-April in Kigoma, Tanzania (CHAPMAN \& VAN WeLL 1978), and in February-May in Burundi (ROEST 1977). In another study at the North end of the lake (Bujumbura subbasin), the main spawning took place well before the first rains as indicated by an abrupt decline of the GSI (MULIMBWA et al. 2014b).

Because of the considerable variability in field-derived indicators across different studies of Lake Tanganyika, it has been difficult to obtain an overview of the timing of reproductive activities in the two species. The breeding peaks vary in height, and in many studies only the major peaks have been identified and considered. It has been difficult to determine whether the minor peaks indeed represent substantial breeding activity. However, data on the occurrence of larvae are meagre, and cohort analyses have been rarely attempted. Especially in the Bujumbura sub-basin, the northernmost and at $350 \mathrm{~m}$ the shallowest sub-basin of Lake Tanganyika, limited information on the spawning areas of L. miodon and S. tanganicae exists. So far, the most detailed studies are those by MANNINI et al. (1996), MöLSÄ et al. (2002) and MULIMBWA et al. (2014a, 2014b). Based on variation in GSI and size-frequency distributions, these studies suggested that in the northern part of the lake, S. tanganicae usually produces three to four annual cohorts. Most of the cohorts are born in the rainy season when zooplankton food is abundant, but strong cohorts also appear in the dry season when zooplankton is scarce. It is likely that the reproduction of this species is closely linked to food availability, but not all factors regulating recruitment success are completely understood.

Here, we aim to identify the nursing areas of both clupeids in the northern part of the lake in space and time based on the occurrence of larvae, and examine the temporal (seasonal) distribution of their reproductive activities through two indices (GSI and proportion of mature individuals). We hypothesize (1) that littoral sandy areas are more important nursing areas of L. miodon than rockier areas; (2) that reproductive activities are limited in time in S. tanganicae, but limited in space in L. miodon; and (3) that reproductive synchrony occurs within, but not between species.

\section{Materials and methods}

\section{Sample collection}

The study was performed in the Bujumbura sub-basin (Fig. 1) in the northern end of Lake Tanganyika $\left(03^{\circ} 28^{\prime} \mathrm{S}\right.$ and $\left.29^{\circ} 17^{\prime} \mathrm{E}\right)$. The rainy season in this area spans from October to April, while the dry season lasts from May to September.

\section{Sampling of larvae}

Larvae of Limnothrissa miodon were sampled in the littoral zone (max. depth less than $2 \mathrm{~m}$ ) from August 2009 to July 2010. Four different beaches were monitored (Fig. 1): (1) mouth of Kalimabenge River (beach covered by 100\% sand), (2) CRH Guest house (beach covered by $80 \%$ sand and macrophytes), (3) Kalundu Congo SEP (mouth of Ruzozi River; beach covered by $60 \%$ sand and $40 \%$ stones), and (4) Kamongola (beach covered by $90 \%$ stones). Limnothrissa miodon larvae were caught by an experimental fishing unit using a mosquito net (mesh size: $0.78 \mathrm{~mm}$ ) operated by two laboratory assistants. This net is rectangular with a pocket in the middle. The lower part of the net was dragged along the bottom whilst keeping the upper part on the surface over a distance of approximately $50 \mathrm{~m}$. At the end of each haul, the net was raised and larvae were placed either in a basin or a bucket. The 
collected larvae were weighed (fresh mass, g) and identified based on morphological characteristics (TSHIBANGU \& KINOSHITA 1995). No larvae of S. tanganicae were encountered.

\section{Sampling of adults}

Adults of Limnothrissa miodon were sampled from March 2013 to January 2014 in the littoral zone (max. depth less than $50 \mathrm{~m}$ ) using a beach seine (mesh size: 6-8 mm), and from March 2013 to December 2016 in the pelagic zone at $7 \mathrm{~km}$ from the shore by artisanal lift net fishing units (max depth $\geq 100 \mathrm{~m}$, mesh size: $6-8 \mathrm{~mm}$ ). Because of the similar mesh size, we assume that both collections give a similar representation of the adult population structure. Adults of Stolothrissa tanganicae were caught only in the pelagic zone from March 2013 to January 2016, also by artisanal fishing units (mesh size: 6-8 mm). Ten individuals of each sex of littoral L. miodon, ten individuals of each sex of pelagic L. miodon, and 15 individuals of each sex of $S$. tanganicae were dissected monthly. Specimens were selected (considered 'adults') based on the cut-off length for sexual maturity, following the scale determined by DE KIMPE (1964), MichA (1973) and PLISNIER et al. (1988). Length was measured for each candidate individual for dissection until enough individuals with the appropriate length had been identified. Gonad weight and stage of maturity was only determined for the selected individuals. The lengths of selected individuals of L. miodon ranged between 80 to $124 \mathrm{~mm}$ total length (TL) and those of $S$. tanganicae from 74 to $100 \mathrm{~mm}$ TL. Fish were measured $(\mathrm{cm})$ and weighed $(\mathrm{g})$. Their gonads were weighed to the nearest $0.01 \mathrm{~g}$ and classified as mature (stage IV) or immature (stage I, II, III) according to a scale of gonad maturity based on gonad size and egg development (DE KIMPE 1964; Micha 1973). Males were considered mature when testes were white and spermiducts were filled with sperm; females were considered mature when ovaries were light yellow to orange and oviducts were filled with ovules. Individuals that had already spawned (stage V) were not encountered.

\section{Data analysis}

Statistical analyses consisted of (1) the identification of nursing areas of L. miodon, (2) the analysis of variation in indices of reproductive activities by habitat, month and season in L. miodon and by month and season in $S$. tanganicae, and (3) the analysis of reproductive synchrony between and within species. Indicators used to describe the reproductive activities included the gonadosomatic index (GSI), defined as the percentage of gonad weight of body weight, and the proportion of mature individuals. All statistical analyses were conducted in R version 4.0.2 (R CORE TEAM 2020).

\section{Nursing areas of $L$. miodon}

The nursing areas were identified by the presence of larvae of L. miodon of less than $19 \mathrm{~mm}$ TL, which are approximately one month old (MULIMBWA et al. 2014b). A chi-squared test for equal proportions (function prop.test) was performed in order to evaluate if the occurrence of larvae differed between the four beaches across more than 30 visits year-round ( 35 visits for site 1 and site $2 ; 31$ visits for site 3 and site 4). Specifically, we were interested in comparing the proportion of occurrence of larvae between the two sandier and the two rockier beaches. In addition, we calculated the mean and median total weight of the catches to compare the abundance of larvae between the sites.

\section{Reproductive activity}

All indices of reproductive activities were analyzed for each species and sex separately. First, overall differences in mean GSI and proportions of mature individuals between the dry season and the rainy season were tested using Student's t-tests and chi-squared test for equal proportions (function prop. test), respectively. Second, reproductive investment in the pelagic habitat was examined with ANOVA, followed by post hoc Tukey tests, testing the fluctuations between months in mean GSI. As the variation in GSI between months might be influenced by cohort structure and size differences, month effects 
on GSI were also tested with an ANCOVA including total length as a covariate. In addition, logistic regression was used to evaluate the significance of month-to-month fluctuations in the proportion of mature individuals. Finally, for the period that data for L. miodon were available for both the pelagic and littoral zone (March 2013-January 2014), we also evaluated in which habitat males and females of L. miodon obtained larger body size, larger mean GSI, and a higher proportion of mature individuals. This was achieved by means of paired t-tests, where the observations of the pelagic and littoral zone were paired by month. For the same period, ANOVA/ANCOVA for GSI and logistic regression for the proportion of mature individuals were implemented as above to test for fluctuations between months.

\section{Reproductive synchrony}

Reproductive synchrony by species in the pelagic habitat was examined with Pearson correlations quantifying synchrony of mean monthly GSI values and proportions of mature individuals, first between the two species within each sex, and second between the two sexes within each species. For L. miodon, reproductive synchrony was additionally examined in the same way, first between the two habitats within each sex, and second between the sexes within each habitat. Finally, synchrony was quantified between sexes across species and habitats.

\section{Results}

\section{Nursing areas of Limnothrissa miodon}

The proportion of occurrence of larvae differed significantly between the four beaches (Table $1 ; \chi^{2}=$ $65.04, \mathrm{df}=3, \mathrm{P}<0.0001)$. Specifically, larvae of L. miodon were frequently encountered in the sandy habitat of site 1 and 2, while they were rarely observed in the rockier habitats of site 3 and 4 (Table 1). The mean and median total weight of the larvae were also markedly higher for the sandier beaches than for the rockier beaches (Table 1). As described previously (MuLimBWA et al. 2014b: fig. 5), these onemonth old larvae (15-19 mm) were common in March and May (i.e., born in February and April in the rainy season), but also occurred from August to October (i.e., born between July and September in the dry season).

\section{Reproductive indices of $\boldsymbol{L}$. miodon by habitat and season}

Direct comparison based on paired t-tests on monthly averages revealed that $L$. miodon of pelagic origin were generally and significantly smaller than L. miodon of littoral origin (males: pelagic mean body size \pm S.E. $=97.1 \pm 0.79$, littoral mean body size \pm S.E. $=104 \pm 0.80, \mathrm{t}_{9}=2.56, \mathrm{P}=0.031$; females: pelagic mean body size \pm S.E. $=95.8 \pm 0.80$, littoral mean body size \pm S.E. $=106 \pm 0.86, \mathrm{t}_{10}=4.00, \mathrm{P}=0.003$ ). Furthermore, L. miodon of pelagic origin had significantly lower GSI values than L. miodon of littoral origin in females (Fig. 2a; pelagic mean GSI \pm S.E. $=2.77 \pm 0.15$, littoral mean GSI \pm S.E. $=3.57 \pm 0.19$, $\mathrm{t}_{10}=-3.10, \mathrm{P}=0.0112$ ), but not in males (Fig. 2a; pelagic mean GSI \pm S.E. $=2.11 \pm 0.08$, littoral mean $\mathrm{GSI} \pm$ S.E. $\left.=1.87 \pm 0.09, \mathrm{t}_{9}=-1.05, \mathrm{P}=0.3192\right)$. Likewise, the proportion of mature individuals was significantly lower in the pelagic than in the littoral habitat for females (Fig. 2b; proportion of mature pelagic females \pm S.E. $=0.29 \pm 0.04$, proportion of mature littoral females \pm S.E. $=0.69 \pm 0.04, t_{10}=$ $6.63, \mathrm{P}<0.001$ ), but not for males (Fig. $2 \mathrm{~b}$; proportion of mature pelagic males \pm S.E. $=0.18 \pm 0.04$, proportion of mature littoral males \pm S.E. $\left.=0.28 \pm 0.05, \mathrm{t}_{9}=1.19, \mathrm{P}=0.263\right)$.

In L. miodon of pelagic origin, no significant differences in mean GSI were found between seasons for either sex (Table 2, male GSI: $\mathrm{t}_{410}=1.426, \mathrm{P}=0.155$; female GSI: $\mathrm{t}_{428}=-0.310, \mathrm{P}=0.757$ ). GSI in pelagic males of $L$. miodon fluctuated significantly between months (Fig. 2a; male GSI: $\mathrm{F}_{44,398}=2.65$, $\mathrm{P}<0.001$ ). Yet, only $2 \%$ of pairwise comparisons between months were significant, indicating one small peak in January 2014 and one in June-July 2015. GSI in pelagic females of L. miodon did not 

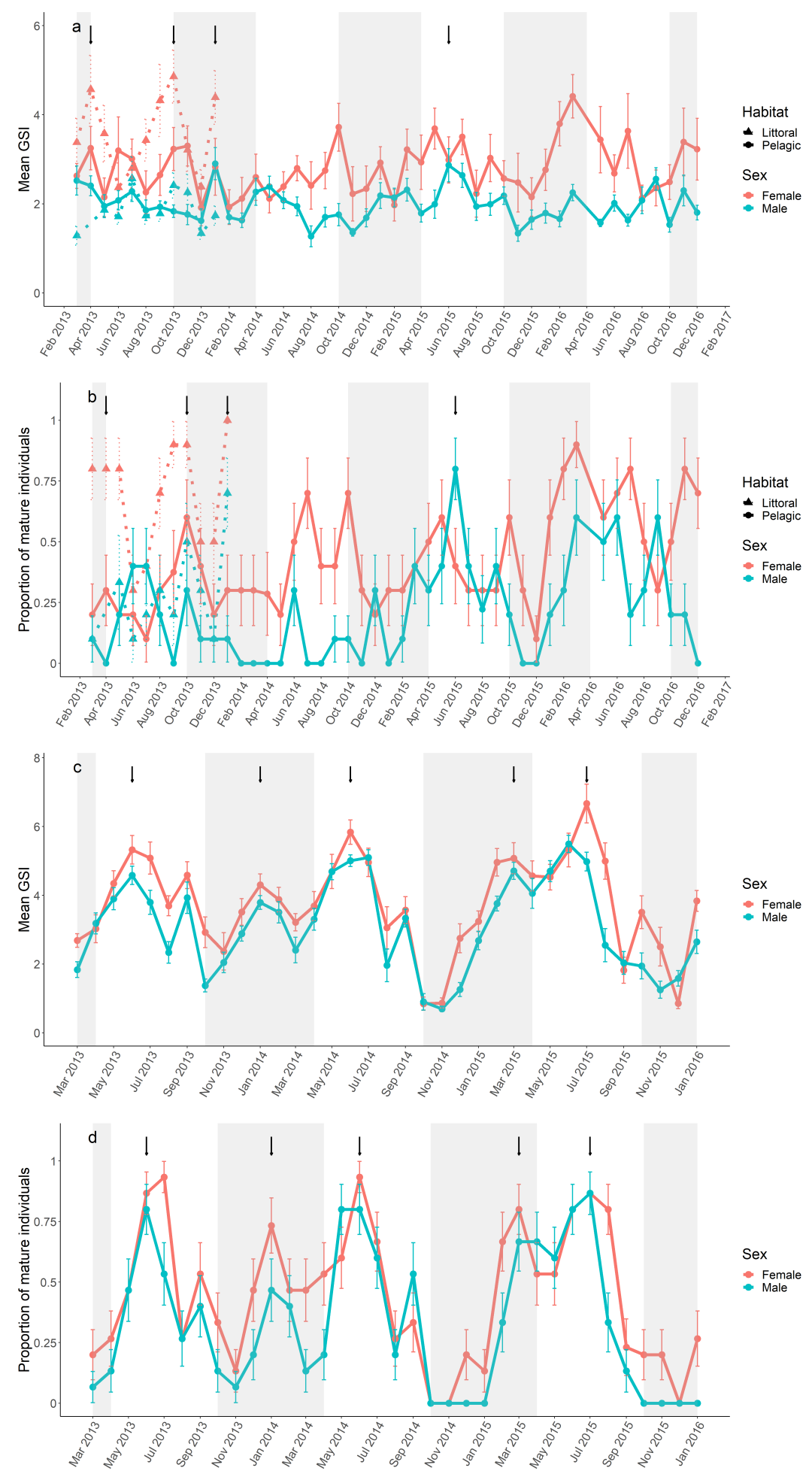

Figure 2 - Reproductive indices of S. tanganicae and L. miodon in the pelagic and littoral habitat by month. Blue and orange lines indicate male and female data, respectively. Line type indicates habitat, and arrows indicate peaks mentioned in the text. Months of the rainy season are shaded. (a) Mean GSI \pm standard error for male and female individuals of L. miodon. (b) Proportion \pm standard error of mature male and female individuals of L. miodon. (c) Mean GSI \pm standard error for male and female individuals of S. tanganicae. (d) Proportion \pm standard error of mature male and female individuals of S. tanganicae. 


\section{TABLE 1}

Occurrence, mean total weight and median total weight of larvae of $L$. miodon at four littoral sites. The occurrence is expressed as the number and percentage of sampling days when larvae were observed.

\begin{tabular}{ccccc}
\hline Site & $\begin{array}{c}\text { Number of } \\
\text { sampling days }\end{array}$ & $\begin{array}{c}\text { Number (\%) of days when } \\
\text { larvae were observed }\end{array}$ & $\begin{array}{c}\text { Mean total } \\
\text { weight (g) }\end{array}$ & $\begin{array}{c}\text { Median total } \\
\text { weight }(\mathbf{g})\end{array}$ \\
\hline $1(100 \%$ sand $)$ & 35 & $25(71 \%)$ & 11.92 & 0.55 \\
$2(80 \%$ sand $)$ & 35 & $28(80 \%)$ & 17.07 & 1.33 \\
$3(60 \%$ sand $)$ & 31 & $3(10 \%)$ & 0.47 & 0 \\
$4(10 \%$ sand $)$ & 31 & $1(3 \%)$ & 0.72 & 0 \\
\hline
\end{tabular}

vary significantly between months (Fig. $2 \mathrm{a}$; female GSI: $\mathrm{F}_{44,400}=1.35, \mathrm{P}=0.073$ ). Male, but not female individuals of $L$. miodon showed significantly higher proportions of mature individuals in the dry than in the rainy season (Table 2, males: $\chi^{2}=15.9, \mathrm{P}<0.001$; females: $\chi^{2}=0.25, \mathrm{P}=0.617$ ). While both sexes showed significant fluctuations in the proportion of mature individuals between months (logistic regression, Fig. $2 \mathrm{~b}$; males: $\chi_{44,397}^{2}=119 \mathrm{P}<0.001$; females: $\chi_{44,400}^{2}=80.5, \mathrm{P}<0.001$ ), these differences could not be linked to specific pairwise comparisons between months.

In L. miodon of littoral origin, the overall mean GSI did not differ between seasons (male GSI: $\mathrm{T}_{94}=$ $-0.71, \mathrm{P}=0.478$; female GSI: $\mathrm{t}_{105}=1.35, \mathrm{P}=0.180$ ) and neither did the proportion of mature individuals (males: $\chi^{2}=1.23, \mathrm{P}=0.268$, females: $\chi^{2}=1.59, \mathrm{P}=0.207$ ). Fluctuations in GSI between months were significant in both males and females (Fig. $2 \mathrm{a}$; male GSI: $\mathrm{F}_{9,86}=2.50, \mathrm{P}=0.014$; female GSI: $\mathrm{F}_{10,99}=$ $2.22, \mathrm{P}=0.023)$. In addition, females showed significant monthly variation in the proportion of mature individuals (logistic regression, Fig. $2 \mathrm{~b}$; males: $\chi_{9,86}^{2}=16.4, \mathrm{P}=0.059$; females: $\chi_{10,99}^{2}=27.4, \mathrm{P}=0.002$ ). While no pairwise comparisons were significant in Tukey post-hoc tests, we observed three strong peaks in GSI and the proportion of mature individuals in April, October and January (Fig. 2a-b). Overall, the percentage of mature individuals frequently exceeded $50 \%$, especially in females.

\section{Reproductive indices of Stolothrissa tanganicae by season}

Mature individuals of S. tanganicae were encountered only in the pelagic area. Both male and female mean GSI were consistently and significantly higher in the dry than in the rainy season (Table 2, male GSI: $\mathrm{t}_{455}=-9.80, \mathrm{P}<0.001$; female GSI: $\left.\mathrm{t}_{459}=8.491, \mathrm{P}<0.001\right)$. Furthermore, fluctuations in both male and female GSI between months were highly significant, primarily through consistent peaks in mean GSI in June-July (Fig. 2c; male GSI: $\mathrm{F}_{34,489}=20.3$, P $<0.001$; female GSI: $\mathrm{F}_{34,488}=11.7$, P < $0.001)$. Smaller peaks were also observed in January and March. Post-hoc analyses revealed significant contrasts in male GSI for $50 \%$ of the pairwise comparisons between months from the dry and the rainy season, $37 \%$ of the pairwise comparisons between months of the dry season, and $35 \%$ of the pairwise comparisons between the months of the rainy season. For females, these percentages were $30 \%$ (dryrainy), $18 \%$ (dry-dry) and 21\% (rainy-rainy). Both sexes also showed significantly higher proportions of mature individuals in the dry season than in the rainy season (Table $2, \chi^{2}=76.9, \mathrm{P}<0.001$ ), and significant variation in the proportion of mature individuals between months, again with clear peaks in June-July, and smaller peaks in January and March (logistic regression, Fig. 2d; males of S. tanganicae: $\chi_{34,489}^{2}=230, \mathrm{P}<0.001$; females of $S$. tanganicae: $\left.\chi_{34,488}^{2}=189, \mathrm{P}<0.001\right)$. Yet, these global fluctuations could not be linked to specific month-to-month comparisons. 


\section{TABLE 2}

Indicators of reproductive investment across subsequent seasons in Lake Tanganyika clupeids. Means and standard error (SE) of Gonadosomatic Index (GSI) and the proportion of mature individuals (Prop) in the sequel of rainy seasons (R1-R5; October to April) and dry seasons (D1-D4; May to September) for males $(\hat{\jmath})$ and females $(+)$ of pelagic S. tanganicae and pelagic and littoral L. miodon. Rainy season 4 (R4) for S. tanganicae was only sampled until January 2016.

\begin{tabular}{|c|c|c|c|c|c|c|c|c|}
\hline & \multicolumn{2}{|c|}{ S. tanganicae $\left({ }^{\lambda}\right)$} & \multicolumn{2}{|c|}{ S. tanganicae $(\uparrow)$} & \multicolumn{2}{|c|}{ L. miodon $\left({ }^{\Uparrow}\right)$} & \multicolumn{2}{|c|}{ L. miodon $(+)$} \\
\hline & $\begin{array}{l}\text { GSI } \\
\text { (SE) }\end{array}$ & $\begin{array}{l}\text { Prop } \\
\text { (SE) }\end{array}$ & $\begin{array}{l}\text { GSI } \\
\text { (SE) }\end{array}$ & $\begin{array}{l}\text { Prop } \\
\text { (SE) }\end{array}$ & $\begin{array}{l}\text { GSI } \\
\text { (SE) }\end{array}$ & $\begin{array}{l}\text { Prop } \\
\text { (SE) }\end{array}$ & $\begin{array}{l}\text { GSI } \\
\text { (SE) }\end{array}$ & $\begin{array}{l}\text { Prop } \\
\text { (SE) }\end{array}$ \\
\hline \multicolumn{9}{|l|}{ Pelagic } \\
\hline R1 (Jan. 2013-Apr. 2013) & $\begin{array}{c}2.51 \\
(0.23)\end{array}$ & $\begin{array}{c}0.1 \\
(0.05)\end{array}$ & $\begin{array}{c}2.86 \\
(0.22)\end{array}$ & $\begin{array}{c}0.23 \\
(0.08)\end{array}$ & $\begin{array}{c}2.46 \\
(0.19)\end{array}$ & $\begin{array}{c}0.05 \\
(0.05)\end{array}$ & $\begin{array}{c}2.94 \\
(0.28)\end{array}$ & $\begin{array}{c}0.25 \\
(0.10)\end{array}$ \\
\hline D1 (May 2013-Sep. 2013) & $\begin{array}{c}3.71 \\
(0.17)\end{array}$ & $\begin{array}{c}0.49 \\
(0.06)\end{array}$ & $\begin{array}{c}4.61 \\
(0.18)\end{array}$ & $\begin{array}{c}0.61 \\
(0.06)\end{array}$ & $\begin{array}{c}2.03 \\
(0.10)\end{array}$ & $\begin{array}{c}0.26 \\
(0.06)\end{array}$ & $\begin{array}{c}2.65 \\
(0.24)\end{array}$ & $\begin{array}{c}0.23 \\
(0.06)\end{array}$ \\
\hline R2 (Oct. 2013-Apr. 2014) & $\begin{array}{c}2.76 \\
(0.13)\end{array}$ & $\begin{array}{c}0.23 \\
(0.04)\end{array}$ & $\begin{array}{c}3.41 \\
(0.16)\end{array}$ & $\begin{array}{c}0.45 \\
(0.05)\end{array}$ & $\begin{array}{c}1.94 \\
(0.10)\end{array}$ & $\begin{array}{c}0.09 \\
(0.03)\end{array}$ & $\begin{array}{c}2.55 \\
(0.19)\end{array}$ & $\begin{array}{c}0.34 \\
(0.06)\end{array}$ \\
\hline D2 (May 2014-Sep. 2014) & $\begin{array}{c}4.02 \\
(0.19)\end{array}$ & $\begin{array}{c}0.59 \\
(0.06)\end{array}$ & $\begin{array}{c}4.42 \\
(0.23)\end{array}$ & $\begin{array}{c}0.56 \\
(0.06)\end{array}$ & $\begin{array}{c}1.88 \\
(0.11)\end{array}$ & $\begin{array}{c}0.08 \\
(0.04)\end{array}$ & $\begin{array}{c}2.49 \\
(0.17)\end{array}$ & $\begin{array}{c}0.44 \\
(0.07)\end{array}$ \\
\hline R3 (Oct. 2014-Apr. 2015) & $\begin{array}{c}2.58 \\
(0.18)\end{array}$ & $\begin{array}{c}0.24 \\
(0.04)\end{array}$ & $\begin{array}{c}3.19 \\
(0.21)\end{array}$ & $\begin{array}{c}0.33 \\
(0.05)\end{array}$ & $\begin{array}{c}1.89 \\
(0.09)\end{array}$ & $\begin{array}{c}0.17 \\
(0.05)\end{array}$ & $\begin{array}{c}2.76 \\
(0.19)\end{array}$ & $\begin{array}{c}0.39 \\
(0.06)\end{array}$ \\
\hline D3 (May 2015-Sep. 2015) & $\begin{array}{c}3.95 \\
(0.22)\end{array}$ & $\begin{array}{c}0.55 \\
(0.06)\end{array}$ & $\begin{array}{c}4.74 \\
(0.28)\end{array}$ & $\begin{array}{c}0.66 \\
(0.06)\end{array}$ & $\begin{array}{c}2.28 \\
(0.14)\end{array}$ & $\begin{array}{c}0.45 \\
(0.07)\end{array}$ & $\begin{array}{c}3.09 \\
(0.22)\end{array}$ & $\begin{array}{c}0.38 \\
(0.07)\end{array}$ \\
\hline R4 (Oct. 2015-Apr. 2016) & $\begin{array}{c}1.86 \\
(0.16)\end{array}$ & $0(0)$ & $\begin{array}{c}2.68 \\
(0.25)\end{array}$ & $\begin{array}{c}0.17 \\
(0.05)\end{array}$ & $\begin{array}{c}1.81 \\
(0.09)\end{array}$ & $\begin{array}{c}0.22 \\
(0.05)\end{array}$ & $\begin{array}{c}3.03 \\
(0.22)\end{array}$ & $\begin{array}{c}0.55 \\
(0.06)\end{array}$ \\
\hline D4 (May 2016-Sep. 2016) & - & - & - & - & $\begin{array}{c}1.97 \\
(0.10)\end{array}$ & $\begin{array}{c}0.44 \\
(0.07)\end{array}$ & $\begin{array}{c}2.85 \\
(0.26)\end{array}$ & $\begin{array}{c}0.58 \\
(0.07)\end{array}$ \\
\hline R5 (Oct. 2016-Dec. 2016) & - & - & - & - & $\begin{array}{c}1.88 \\
(0.15)\end{array}$ & $\begin{array}{c}0.13 \\
(0.06)\end{array}$ & $\begin{array}{c}3.03 \\
(0.36)\end{array}$ & $\begin{array}{c}0.67 \\
(0.09)\end{array}$ \\
\hline \multicolumn{9}{|l|}{ Littoral } \\
\hline R1 (Mar. 2013-Apr. 2013) & - & - & - & - & $\begin{array}{c}1.28 \\
(0.21)\end{array}$ & $\begin{array}{c}0.10 \\
(0.09)\end{array}$ & $\begin{array}{c}3.97 \\
(0.47)\end{array}$ & $\begin{array}{c}0.80 \\
(0.09)\end{array}$ \\
\hline D1 (May 2013-Sep. 2013) & - & - & - & - & $\begin{array}{c}1.94 \\
(0.13)\end{array}$ & $\begin{array}{c}0.22 \\
(0.06)\end{array}$ & $\begin{array}{c}3.30 \\
(0.27)\end{array}$ & $\begin{array}{c}0.62 \\
(0.07)\end{array}$ \\
\hline R2 (Oct. 2013-Jan. 2014) & - & - & - & - & $\begin{array}{c}1.94 \\
(0.15)\end{array}$ & $\begin{array}{c}0.40 \\
(0.08)\end{array}$ & $\begin{array}{c}3.71 \\
(0.30)\end{array}$ & $\begin{array}{c}0.73 \\
(0.07)\end{array}$ \\
\hline
\end{tabular}

\section{Reproductive synchrony between and within species}

Pelagic males and females of $S$. tanganicae were strongly synchronized in their reproductive effort (GSI: $\mathrm{r}_{\text {Pearson }}=0.882, \mathrm{P}<0.001$; Figs $2 \mathrm{c}, 3 \mathrm{a}$; proportion of mature individuals: $\mathrm{r}_{\text {Pearson }}=0.849, \mathrm{P}<0.001$; Fig. 2b, d), while pelagic males and females of L. miodon were not (Figs $2 \mathrm{a}-\mathrm{b}, 3$ ). The proportions of mature males and females of littoral L. miodon were significantly correlated $\left(\mathrm{r}_{\text {Pearson }}=0.65, \mathrm{P}=0.044\right.$, Figs 2a, 3b). Significant correlations between same sex individuals between the two species showed that indices of reproductive investment were synchronized between pelagic males of $S$. tanganicae and 
L. miodon (GSI: $\mathrm{r}_{\text {Pearson }}=0.60, \mathrm{P}<0.001$; proportion of mature individuals: $\mathrm{r}_{\text {Pearson }}=0.50, \mathrm{P}=0.002$; Figs 2-3) but not between pelagic females of the two species (Figs 2-3).

Significant correlations between opposite sex individuals between species showed that pelagic males of $L$. miodon were synchronized with pelagic females of $S$. tanganicae (GSI: $\mathrm{r}_{\text {Pearson }}=0.53, \mathrm{P}<0.001$; proportion of mature individuals: $\mathrm{r}_{\text {Pearson }}=0.49, \mathrm{P}=0.003$ ), but not vice versa (Fig. 3 ).

Individuals of the same sex were not significantly synchronized between pelagic and littoral L. miodon in either males or females (Figs 2a-b, 3). Individuals with opposite sex were not synchronized between habitats (Fig. 3). Detailed correlation plots for GSI and proportion of mature individuals between and within species are provided in Supplementary Figure 1.

\section{Discussion}

Presently, as overfishing is threatening the recruitment, and therefore also the fishery of the indigenous clupeid fish in Lake Tanganyika (MUlimbwa 2006; Mulimbwa et al. 2014a, 2014b, 2019; VAN DER KNAAP et al. 2014; DE KEYZER et al. 2020), the periodicity of their reproduction is of great interest. Inferences on breeding activities are usually based on the GSI and the proportion of fish with ripe gonads. Because of natural variability, short term changes in these indicators may not be sufficient for distinguishing all spawning periods. In this study, we aimed to overcome these limitations for the northern part of Lake Tanganyika. First, by identifying nursing areas based on the presence of newlyhatched larvae of $L$. miodon, we obtained a more accurate view of when and where breeding activities take place for this species. Second, by conducting the longest time series of reproductive indices in adult clupeids so far (35 months in S. tanganicae; 46 months in L. miodon), we gained better understanding of the variation in the seasonal distribution of reproductive activities. Below we discuss our findings in more detail, and address implications for fisheries management.

\section{Nursing areas of $L$. miodon}

Our comparison of two sandy beaches and two rockier beaches for the presence of one month old larvae $(15-19 \mathrm{~mm})$ indicated that the larvae were much more frequently encountered at the sandy beaches. Indeed, larvae of L. miodon occurred at all littoral sites, but most frequently and abundantly at the Kalimabenge river mouth (beach covered by $100 \%$ sand) and at the CRH Guest house (beach with $80 \%$ sand covered by macrophytes). Larvae of $L$. miodon inhabiting these beaches have a sandlike coloration (personal observation), possibly a strategy to avoid visual predation. In addition, there may be fewer predators over the shallow sandy habitat. From a previously conducted complementary temporal analysis of the same data (MUlimBwA et al. 2014b: fig. 5; see Supplementary Figure 2 for a small correction in the data), we know that these larvae occur almost year-round, with peaks in March, May, August and October. A more complete overview of all cohorts can be obtained from the presence of newly-hatched larvae, or through the identification of successive cohorts based on size-frequency distributions (e.g., MulimBWA et al. 2014a).

\section{Indices of reproductive activities of adult $L$. miodon and $S$. tanganicae}

The present data covering several years support earlier indications that the clupeids in Tanganyika have species-specific breeding areas and temporal spawning patterns.

\section{Limnothrissa miodon}

Our comparison of size and reproductive indices between the littoral and pelagic habitat suggest that the littoral is the main spawning habitat for L. miodon, while the pelagic habitat might be used primarily for 

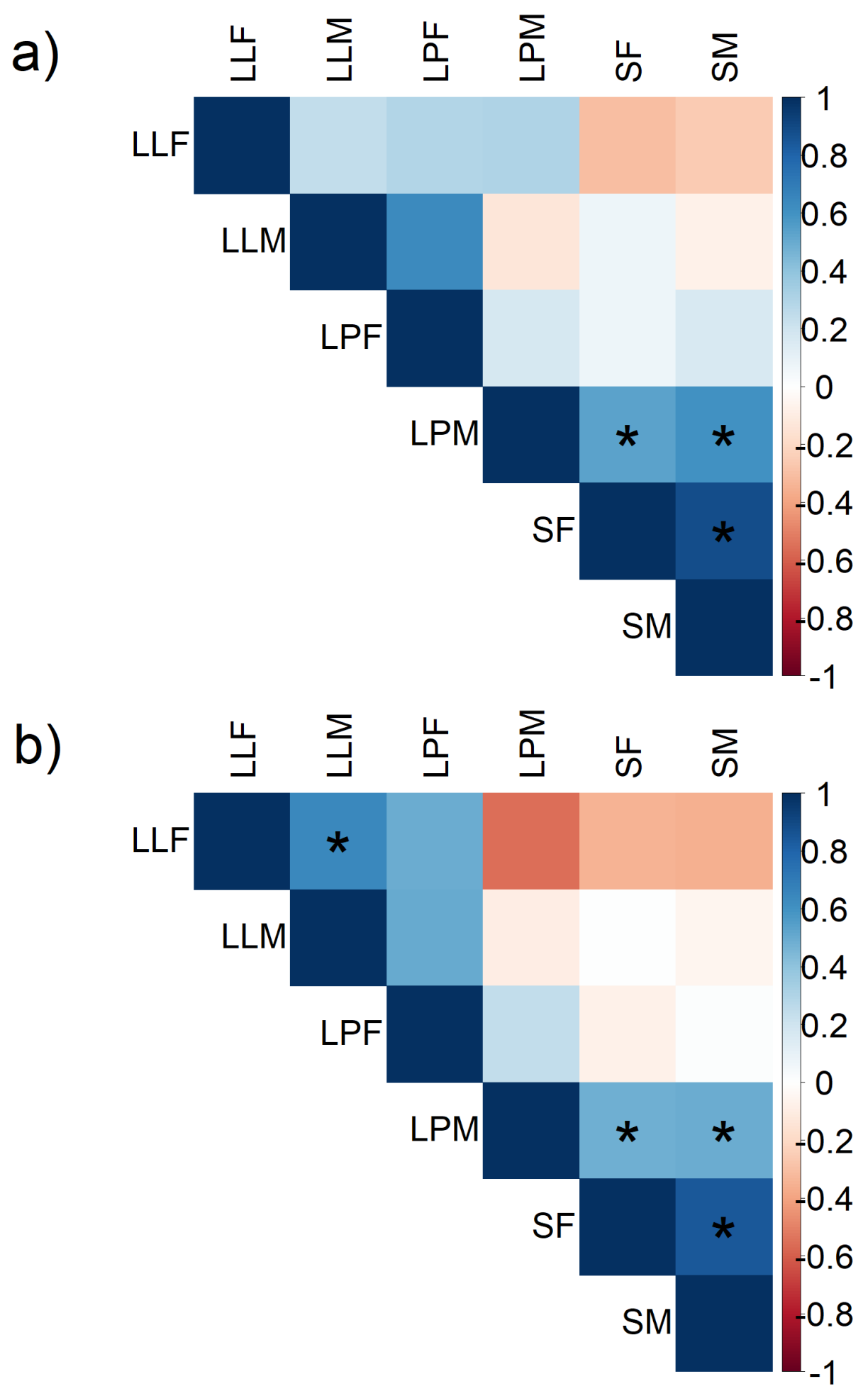

Figure 3 - Synchrony of indices of reproductive activity between L. miodon and S. tanganicae across species, sexes and habitats. The squares show pairwise Pearson correlations (indicated by the colour scale) between species, sexes and habitats for monthly means of (a) GSI and (b) proportion of mature individuals. Statistically significant correlations are indicated by *. Abbreviations: LLF $=$ L. miodon littoral females; $\mathrm{LLM}=$ L. miodon littoral males; $\mathrm{LPF}=$ L. miodon pelagic females; $\mathrm{LPM}=$ L. miodon pelagic males; $\mathrm{SF}=$ S. tanganicae pelagic females; $\mathrm{SM}=$ S. tanganicae pelagic males. 
feeding. Individuals of L. miodon were larger and females had higher reproductive indices in the littoral than in the pelagial. Furthermore, while there were some fluctuations in reproductive indices in the pelagial, these peaks were mostly lower than in the littoral and did not coincide with the littoral peaks. Together, this provides strong evidence for the preference of $L$. miodon for spawning in the littoral habitat (MATTHES 1967; COUlTER 1991). However, because the shores of Tanganyika are open and steep, the pelagic water mass extends its influence almost to the shoreline (CORMAN et al. 2010). The true littoral of Tanganyika is thus very narrow, and fish larvae actually originating from the littoral can easily drift to the open lake. Furthermore, adults could easily migrate between the two habitats. Accordingly, although the number of mature females was lower in the pelagical realm, mature individuals of L. miodon were observed in both habitats in our study. While MATTHES (1967) suggested that the spawning of L. miodon in the South takes place in near-shore waters less than $130 \mathrm{~m}$ deep, the spawning depth in the northern end is likely shallower because of the different bathymetry and the decreased thickness of the oxygenated layer (MATTHES 1967; PLISNIER 1997). A related source of confusion in previous studies on the spawning areas of L. miodon was the delimitation of the littoral zone in different parts of Lake Tanganyika. In limnological vocabulary, 'littoral' denotes the euphotic near-shore zone in which there is still enough light for photosynthesis at the bottom. In the clear-water conditions of the Bujumbura subbasin, this means areas shallower than $50 \mathrm{~m}$.

Seasonal variation in reproductive activities in L. miodon was limited in our study. Only male L. miodon in the pelagic had significantly higher reproductive indices in the dry than in the rainy season. This is in accordance with the synchronization of these males with $S$. tanganicae males and females. As mentioned above, it is possible that mature females of L. miodon migrate to the littoral area and therefore that the proportion of mature females in the pelagic does not peak at any particular time of the year.

In contrast to earlier studies, but in agreement with Mulimbwa et al. (2014a, 2014b), these results suggest that L. miodon may produce strong cohorts at any time of the year, not only from August to October, or between November to May, as suggested in previous studies (MATTHES 1967; ElLIS 1971; Pearce 1985; Mulimbwa \& Shirakihara 1994; Aro \& ManNini 1995). However, it is important to note that several of those studies have been based on observations in the South of the lake where the seasonality in environmental conditions and the production of plankton is more pronounced than in the North (LANGENBERG et al. 2002). In the North, variation in the timing of reproduction in L. miodon may reflect year-to-year variation in limnological conditions and food availability, both of which are undergoing fluctuations due to the climate change (PLISNIER et al. 1999).

\section{Stolothrissa tanganicae}

In our study, mature $S$. tanganicae were only found in the open lake, and $S$. tanganicae larvae were not found in the littoral area. A previous study found young Stolothrissa larger than 35 to $38 \mathrm{~mm}$ inshore mostly between November and early January (COULTER 1970). In our 2013-2016 time series, both reproductive indices, GSI and the percentage of individuals with ripe gonads showed distinct peaks, which were strongly synchronized between the sexes. The highest peaks were in the dry season, with abrupt declines around August. This is in accordance with the results of MulimBWA et al. (2014a, 2014b), who also found that the strongest annual cohort was born in the dry season, when the copepod zooplankton biomass was at its minimum. The second strongest peaks of the reproductive indices, implying spawning in the next month, were in the rainy season (January and March).

The environmental conditions of the dry season (May-September) are dominated by strong south-east winds tilting the thermocline. At the end of the dry season (August/September), a secondary upwelling takes place bringing water from the metalimnion-hypolimnion with high nutrient levels into the epilimnion allowing an increased primary production probably favourable for the larvae of the clupeids 
(LANGENBERG et al. 2002). At the end of dry season (August/September), the southeast winds stop and the increased solar radiation and temperature in October particularly induce a stronger stratification while large-scale hydrological movements inside the lake take place. Starting rains bring additional nutrients, especially in the littoral zone, and together with the secondary upwelling of nutrient-rich waters induce algal blooms that result in high zooplankton biomasses. Zooplankton is the main food of S. tanganicae, and the larvae of both clupeids feed on copepod nauplii. Assuming bottom-up regulation of the pelagic food web in Tanganyika, zooplankton abundance could therefore contribute to the seasonal cohorts of the clupeids (PLISNIER et al. 1999; LANGENBERG et al. 2002). However, our results show that the reproductive investment of $S$. tanganicae was high in the dry season followed by an abrupt decline in July-August, suggesting that the main spawning happened before the end of dry season and the beginning of rainy season period, i.e., before the abundance peak of plankton. The success of several cohorts of $S$. tanganicae therefore seems to be linked to rainfall and abundance of copepods, but sometimes in species with fluctuating populations, strong cohorts could arise even under poor food conditions. A strong initial cohort born under exceptionally favorable conditions is likely to produce strong subsequent cohorts for several generations, even if food abundance decreases. The effect of such abundance peaks decreases over time, but can be observed up to the tenth generation (TOWNSEND et al. 1989; JANSEN et al. 1990; FOGARTY et al. 1991; KAITALA et al. 1996). However, in our dataset of S. tanganicae, the dry season peaks are always stronger than the wet season peaks, and their periodicity is very consistent. We also observed no gradual decrease in peak height, both suggesting that random effects played little to no role in the patterns we observed for this species.

\section{Reproductive synchrony within and across species}

The synchrony of the reproductive cycles, indicated by significant Pearson correlations, between male and female L. miodon in the littoral habitat, and between male and female $S$. tanganicae in the pelagic reflects their different spawning habitat preferences. This is further confirmed by the lack of synchrony between L. miodon from pelagic and littoral habitats. Interestingly, however, in the pelagic habitat, males of $L$. miodon were in reproductive synchrony with females of $S$. tanganicae, and even more so with males of $S$. tanganicae. This synchrony was mostly driven by coinciding peaks in June. There are no conclusive reports of reproductive interaction (e.g., hybridization) between L. miodon and S. tanganicae, so this pattern is likely explained by both species following the seasonality of limnological conditions.

\section{Conclusions and recommendations for fisheries management}

The preferred nursery areas of L. miodon were the sandy beaches, which likely protect the larvae against predation. Mature individuals were encountered in both littoral and pelagic areas, but peaks of indices of reproductive activity in the littoral were more pronounced. The peaks were also only synchronized between males and females in the littoral. No significant difference in indices of reproductive activities was found between the dry and rainy seasons, except for pelagic males. This is likely linked to synchrony with fluctuations in limnological parameters.

Stolothrissa tanganicae is a pelagic spawner and its larvae have not been encountered in the littoral zone. Based on GSI and the percentage of individuals with ripe gonads, its major reproductive activities took place in the dry season, and low values were recorded at the end of the dry season. The indices of males and females were strongly synchronized.

Based on our observations, we recommend that sandy beaches, which are the main breeding grounds for L. miodon, should be protected year-round. Suggested measures include increased enforcement of the ban on larvae fishing, forbidding extraction of sand and aquatic vegetation, and afforestation of the 
hillside overhanging the lake shore in order to decrease sedimentation which can coat L. miodon eggs and larvae.

\section{Acknowledgements}

We thank the scientific staff of the Center of Hydrobiological Research (C.R.H) for field support.

\section{References}

ARo E. \& MANNINI P. (1995). Résultats des études de la biologie des populations des poissons sur le lac Tanganyika pendant la période de Juillet 1993 - Juin 1994. FAO/FINNIDA Recherche pour l'aménagement des Pêches au Lac Tanganyika. GCP/RAF/271/FIN-TD/38 (Fr): 115 pp.

COCQuYT C., Plisnier P.-D., MulimbWA N.T. \& NSHOMBO M.V. (2021). Unusual massive phytoplankton bloom in the oligotrophic Lake Tanganyika. Plant Ecology and Evolution 154: 351-361.

https://doi.org/10.5091/plecevo.2021.1890

Cohen A.S. , Bills R., Cocquyt C.Z. \& CALjon A.G. (1993). Impact of sediment pollution on biodiversity in Lake Tanganyika. Conservation Biology 7: 667-677.

https://doi.org/10.1046/j.1523-1739.1993.07030667.x

Corman J.R., Mcintyre P.B., Kuboja B., Bemba W., Fink D., Wheeler C.W., Gans C., Michel E. \& FLECKER A.S. (2010). Upwelling couples chemical and biological dynamics across the littoral and pelagic zones of Lake Tanganyika, East Africa. Limnology and Oceanography 55: 214-224.

https://doi.org/10.4319/10.2010.55.1.0214

Coulter G.W. (1961). Lake Tanganyika Research. Annual Report, Joint Fisheries Research Organisation, Zambia 10: 7-30.

COULTER G.W. (1970). Population changes within a group of fish species in Lake Tanganyika following their exploitation. Journal of Fish Biology 2: 329-353.

https://doi.org/10.1111/j.1095-8649.1970.tb03292.x

COULTER G.W. (1991). Lake Tanganyika and its Life. Natural History Museum and Oxford University Press, London. 354 pp.

CHAPMAN D.W. \& VAN Well P. (1978). Growth and mortality of Stolothrissa tanganicae. Transactions of the American Fisheries Society 107: 26-35. https://doi.org/fgpbqh

De Keyzer E.L.R., De Corte Z., Van Steenberge M., Raeymaekers J.A.M., Calboli F.C.F., Kmentová N., Mulimbwa N., Virgilio M., Vangestel C., Mulungula P.M., VolcKaert F.A.M. \& VANHOVE M.P.M. (2019). First genomic study on Lake Tanganyika sprat Stolothrissa tanganicae: a lack of population structure calls for integrated management of this important fisheries target species. BMC Evolutionary Biology 19: 6. https://doi.org/10.1186/s12862-018-1325-8

De Keyzer E.L.R., Masilya Mulungula P., Alunga lufungula G., Amisi Manala C., Andema

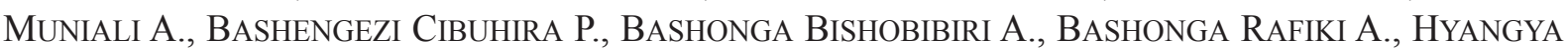
Lwikitcha B., Hugé J., Huyghe C.E.T., Itulamya Kitungano C., Janssens de Bisthoven L., Kakogozo Bombi J., Kamakune Sabiti S., Kiriza Katagata I., Kwibe Assani D., Lubunga Dunia P., Lumami Kapepula V., Lwacha F., MaZambi Lutete J., Shema Muhemura F., Milec L.J.M., Mulimbwa N'Sibula T., Mushagaulusa Mulega A., Muterezi Bukinga F., Muzumani Risasi D., MwenYemali Banamwezi D., Kahindo N'DJungu J., Nabintu Bugabanda N., NTAKobajira KaRANi J.-P., RAEYMAEKERS J.A.M., Riziki WALUMONA J., SAFARI RuKahUSA R., VANHOVE M.P.M., Volckaert F.A.M., Wembo Ndeo O. \& VAn SteEnBerge M. (2020). Local perceptions on the state 
of fisheries and fisheries management at Uvira, Lake Tanganyika, DR Congo. Journal of Great Lakes Research 46: 1740-1753. https://doi.org/10.1016/j.jglr.2020.09.003

DE KimPE P. (1964). Contribution à l'étude hydrobiologique du Luapula-Moero. Annales du Musée royal d'Afrique centrale 8: 128-238.

ELLIS C.M.A. (1971). The size at maturity and breeding seasons of sardines in the southern Lake Tanganyika. African Journal of Tropical Hydrobiology and Fisheries 1: 59-66.

FOGARTY M.J., SisSENWINE M.P. \& COHEN E.B. (1991). Recruitment variability and the dynamics of exploited marine populations. Trends in Ecology \& Evolution 6: 241-246.

https://doi.org/10.1016/0169-5347(91)90069-A

JANSEN V.A.A., NisBet R.M. \& GuRNEY W.S.C. (1990). Generation cycles in stage structured populations. Bulletin of Mathematical Biology 52: 375-396.

Junker J., Rick J.A., Mcintyre P.B., Kimirei I., Sweke E. A., Mosille J. B., Wehrli B., Dinkel C., Mwaiko S., SeEhausen O. \& Wagner C. E. (2020). Structural genomic variation leads to genetic differentiation in Lake Tanganyika's sardines. Molecular Ecology 29: 3277-3298.

https://doi.org/10.1111/mec.15559

HENDERSON H.F. (1976). On the large size of Limnothrissa in the catches of the ring-net fishery in Tanzania. FAO Report No. FI / URT / 71/012/29: 5-9.

KAITALA V., RANTA E. \& LindSTRÖM J. (1996). External perturbations and cyclic dynamics in stable populations. Annales Zoologici Fennici 33: 275 - 282.

Kmentová N., Koblmüller S., Van Steenberge M., RaeymaeKers J.A.M., Artois T., De Keyzer E.L.R., Milec L., Muterezi Bukinga F., Mulimbwa N., Mulungula P.M., Ntakimazi G., VolCKAerT F.A.M., Gelnar M. \& VANHOVE M.P.M. (2020). Weak population structure and recent demographic expansion of the monogenean parasite Kapentagyrus spp. infecting clupeid fishes of Lake Tanganyika, East Africa. International Journal for Parasitology 50: 471-486.

https://doi.org/10.1016/j.ijpara.2020.02.002

Kolding J., van Zwieten P., Marttin F., Funge-Smith S. \& Poulain F. (2019). Freshwater Small Pelagic Fish and Fisheries in Major African Lakes and Reservoirs in Relation to Food Security and Nutrition. FAO Fisheries and Aquaculture Technical Paper No. 642. Rome, FAO. 124 pp.

Langenberg V., Mwape L.W., Tschibangu K., Tumba J.-M., Koelmans A.-A., Roijackers R., SALONEN K., SARVALA J. \& MÖlSÄ H. (2002). Comparison of thermal stratification, light attenuation and Chlorophyll-a dynamics between the ends of Lake Tanganyika. Aquatic Ecosystem Health \& Management 5: 255-265. https://doi.org/10.1080/14634980290031956

Lavoué S., Miya M., Musikasinthorn P., Chen W.J. \& Nishida M. (2013). Mitogenomic Evidence for an Indo-West Pacific Origin of the Clupeoidei (Teleostei: Clupeiformes). PLoS One 8 (2): e56485. https://doi.org/10.1371/journal.pone.0056485

Mannini P., Aro E. Katonda I., Kassaka B., Mambona C., Milindi E., Paffen P. \& Verburg P. (1996). Pelagic Fish Stocks of Lake Tanganyika: Biology and Exploitation. FAO/FINNIDA/ Research for the Management of the Fisheries on Lake Tanganyika. GCP/ RAF/ 271/ FIN - TD/53 FAO ROME (En): $85 \mathrm{pp}$.

MATthes H. (1967). Preliminary investigations into the biology of the Lake Tanganyika Clupeidae. Fisheries Research Bulletin of Zambia 4: 39-46.

MichA J.-C. (1973). Etude des populations piscicoles de l'Oubangui et tentatives d'élection et d'adaptation de quelques espèces à l'étang de pisciculture. CTFT. Paris. 110 pp. 
Micha J.-C., Bangulu B-L.N., Ibofa R., Mumba F., Mutambwe S., Zanga N., Willem E., Svensson J.-E. \& WiLANDER A. (2018). Une ressource insoupçonnée mais déjà surexploitée, Nannothrissa stewarti, au lac Maï-Ndombe (RD Congo). Résultat imprévu du Programme national de Lutte contre le Paludisme (PNLP). ARSOM, Bulletin des Séances de l'Académie royal des Sciences Outre-Mer 64 (1): 61-91. https://doi.org/10.5281/zenodo.3980731

MÖlsä H., ReYNOLdS J.E., COENEN E. \& LindQvist O.V. (1999). Fisheries research towards resource management on Lake Tanganyika. Hydrobiologia 407: 1-24. https://doi.org/10.1023/A:1003712708969

Mölsä H., Sarvala J., Badende S., Chitamwebwa D., Kanyaru R., Mulimbwa N. \& Mwape L. (2002). Ecosystem monitoring in the development of sustainable fisheries in Lake Tanganyika. Aquatic Ecosystem Health \& Management 5: 267-281. https://doi.org/10.1080/14634980290031965

Mulimbwa N. (2006). Assessment of the commercial artisanal fishing impact on three endemic pelagic fish stocks, Stolothrissa tanganicae, Limnothrissa miodon and Lates stappersi, in Bujumbura and Kigoma sub-basins of the Lake Tanganyika. Verhandlungen Internationale Vereinigung für theoretische und angewandte Limnologie 29: 1189-1193. https://doi.org/10.1080/03680770.2005.11902872

MULIMBWA N. \& SHIRAKIHARA K. (1994). Growth, recruitment and reproduction of sardines (Stolothrissa tanganicae and Limnothrissa miodon) in northwestern Lake Tanganyika. Tropics 4: 57-67. https://doi.org/10.3759/tropics.4.57

Mulimbwa N., RAeYMAeKers J.A.M. \& SARVAla J. (2014a). Seasonal changes in the pelagic catch of two clupeid zooplanktivores in relation to the abundance of copepod zooplankton in the northern end of Lake Tanganyika. Aquatic Ecosystem Health \& Management 17: 25-33. https://doi.org/10.1080/14634988.2014.883896

Mulimbwa N., Sarvala J. \& Raeymaekers J.A.M. (2014b). Reproductive activities of two zooplanktivorous clupeid fish in relation to the seasonal abundance of copepod prey in the northern end of Lake Tanganyika. Belgian Journal of Zoology 144: 77-92. https://doi.org/10.26496/bjz.2014.68

Mulimbwa N., Sarvala J. \& Micha J.-C. (2019). The larval fishery on Limnothrissa miodon in the Congolese waters of Lake Tanganyika: impact on exploitable biomass and the value of the fishery. Fisheries Management and Ecology 26: 444-450. https://doi.org/10.1111/fme.12309

PEARCE M.J. (1985). A description and stock assessment of the pelagic fishery in the southeast arm of the Zambian waters of Lake Tanganyika. Report of the Department of Fisheries, Zambia: 1-74.

PliSNIER P.-D. (1997). Climate, Limnology, and Fisheries Changes of Lake Tanganyika. FAO/FINNIDA Research for the Management of Fisheries on Lake Tanganyika. GCP/RAF/271/FIN-TD/72 (En) 38p.

PlisNier P.-D., J.-C Micha \& V. FrAnK (1988). Pêche et biologie des principales espèces de poissons du lac Ihema (Rwanda). Presses universitaires de Namur, 212 pp.

Plisnier P.-D., Chitamwebwa D., Mwape L., Tshibangu K.K., Langenberg V. \& Coenen E. (1999). Limnological annual cycle inferred from physical-chemical fluactuations at three stations of Lake Tanganyika. Hydrobiologia 407: 45-58. https://doi.org/10.1023/A:1003762119873

Plisnier P.-D., Mgana H., Kimirei I., Chande A., Makasa L., Chimanga J., Zulu F., Cocquyt C., Horion S., Bergamino N., NAithani J., DeleERSNiJder E., ANDrÉ L., DeSCy J.P. \& CORNET Y. (2009). Limnological variability and pelagic fish abundance (Stolothrissa tanganicae and Lates stappersii) in Lake Tanganyika. Hydrobiologia 625: 117-134. https://doi.org/10.1007/s10750-009-9701-4

POLL M. (1974). Synopsis et distribution géographique des Clupeidae d'eau douce africaines, descriptions de trois espèces nouvelles. Bulletin de l'Académie royale de Belgique 60 (2): 141-161.

https://doi.org/10.3406/barb.1974.60868 
R CORE Team (2020). R: A language and environment for statistical computing. R Foundation for Statistical Computing, Vienna, Austria. Available from https://www.R-project.org/ [accessed 24 January 2022].

RoEST F.C. (1977). Stolothrissa tanganicae, population dynamics, biomass evolution and life history in the Burundi waters of Lake Tanganyika. United Nations Food and Agriculture Organisation. CIFA Technical Paper 5: 42-63.

Ronco F., BÜscher H.H., Indermaur A. \& SAlZburger W. (2020). The taxonomic diversity of the cichlid fish fauna of ancient Lake Tanganyika, East Africa. Journal of Great Lakes Research 46: 10671078. https://doi.org/10.1016/j.jglr.2019.05.009

Salzburger W., Van BocXlaer B. \& Cohen A.S. (2014). Ecology and Evolution of the African Great Lakes and Their Faunas. Annual Review of Ecology, Evolution, and Systematics 45: 519-545. https://doi.org/10.1146/annurev-ecolsys-120213-091804

Sarvala J., Langenberg V.T., Salonen K., Chitamwebwa D., Coulter G.W., Huttula T., Kanyaru R., Kotilainen P., Makasa L., Mulimbwa N. \& Mölsä H. (2006). Fish catches from Lake Tanganyika mainly reflect changes in fishery practices, not climate. Verhandlungen Internationale Vereinigung für theoretische und angewandte Limnologie 29: 1182-1188.

https://doi.org/10.1080/03680770.2005.11902871

SNOEKS J. (2000). How well known is the ichthyodiversity of the large East African lakes? Advances in Ecological Research 31: 17-38. https://doi.org/10.1016/S0065-2504(00)31005-4

Symoens J.J. (1955). Sur le maximum planctonique observé en fin de saison sèche dans le bassin nord du lac Tanganyika. Folia Scientiae Africae Central 1: 12 pp

TierCelin J.J. \& Mondeguer (1991). The geology of the Tanganyika trough. In: Coulter G.W. (ed.) Lake Tanganyika and its Life: 7-48. Oxford University Press, London, Oxford and New York.

TOWNSEND C.R. (1989). Population cycles in freshwater fish. Journal of Fish Biology 35 (Supplement A): 125-131. https://doi.org/10.1111/j.1095-8649.1989.tb03053.x

TShiBANGU K.K. \& Kinoshita I. (1995). Early life histories of two clupeids Limnothrissa miodon and Stolothrissa tanganicae, from Lake Tanganyika. Japanese Journal of Ichthyology 42 (1): 81-87. https://doi.org/10.11369/jji1950.42.81

VAN DER KNAAP M., KATONDA K.I. \& DE GRAAF G.J. (2014). Lake Tanganyika fisheries frame survey analysis: assessment of the options for management the fisheries of Lake Tanganyika. Aquatic Ecosystem Health \& Management 17: 4-13. https://doi.org/10.1080/14634988.2014.882733

Van Steenberge M., Vanhove M.P.M., Muzumani R.D., Mulimbwa N., Muterezi B.F., Pariselle A., Gillardin C., Vreven E., Raeymaekers J.A.M., Huyse T., Volckaert F.A.M., Nshombo MuderhwA V. \& SNOEKS J. (2011). A recent inventory of the fishes of the north-western and central western coast of Lake Tanganyika (Democratic Republic Congo). Acta Ichthyologica et Piscatoria 41: 201-214. https://doi.org/10.3750/AIP2011.41.3.08

WHITEHEAD P.J.P. (1985). FAO Species Catalogue 7. Clupeoid fishes of the world (suborder Clupeoidei). An annotated and illustrated catalogue of the herrings, sardines, pilchards, sprats, shads, anchovies and wolf- herrings. Part 1 - Chirocentridae, Clupeidae and Pristigasteridae. FAO Fisheries Synopsis 125 (7/1): 1-303.

Manuscript received: 13 May 2021

Manuscript accepted: 15 January 2022

Published on: 3 February 2022

Branch editor: Luc Brendonck 


\section{Supplementary material}

a)

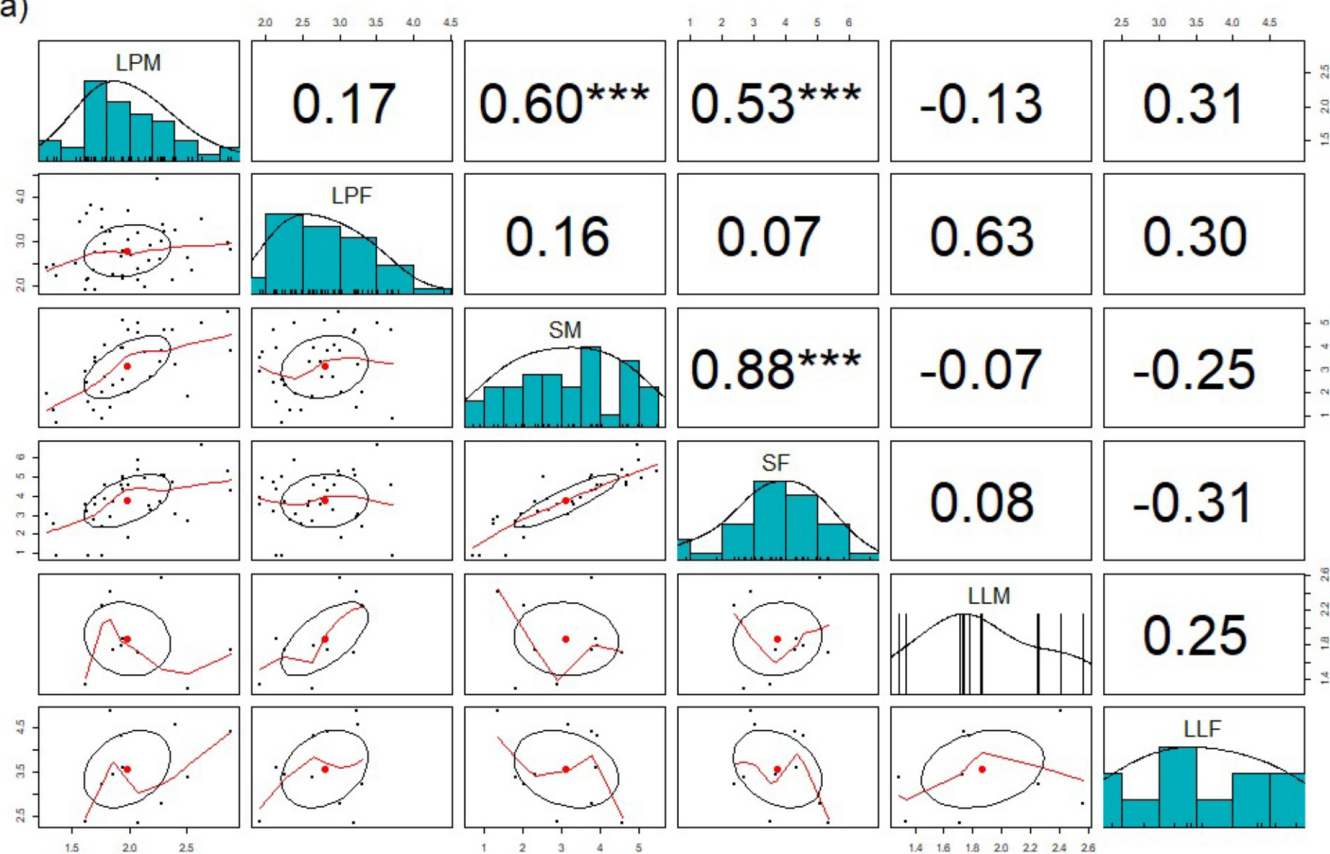

b)

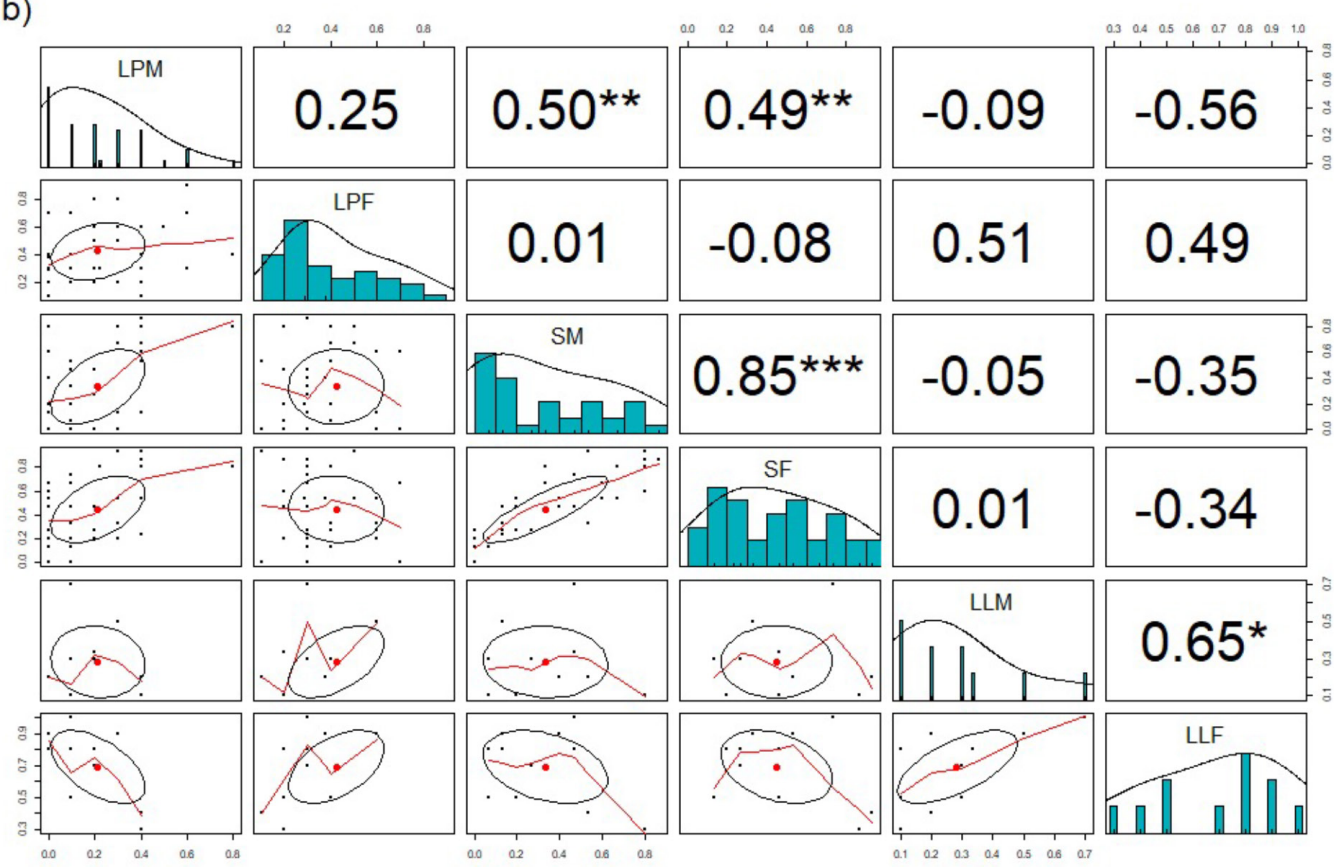

Supplementary Figure 1 - Detailed correlations between S. tanganicae and L. miodon across species, sexes and habitats. Correlations are calculated for monthly means of a) GSI and b) proportion of mature individuals. Panels on the diagonal show histograms of each group. Panels above the diagonal show Pearson correlations between the groups. Statistical significance levels are indicated by asterisks $(*<0.05$, $* *<0.01, * * *<0.001)$. Panels below the diagonal show scatterplots, where each black dot represents one individual, red lines represent lowess locally fit regressions, and an ellipse is drawn around the mean (red dot) with the axis length reflecting one standard deviation of the $\mathrm{x}$ and $\mathrm{y}$ variables. Abbreviations: $\mathrm{LLF}=$ L. miodon littoral females, $\mathrm{LLM}=$ L. miodon littoral males, LPF $=$ L. miodon pelagic females, $\mathrm{LPM}=$ L. miodon pelagic males, $\mathrm{SF}=S$. tanganicae pelagic females, $\mathrm{SM}=S$. tanganicae pelagic males. 

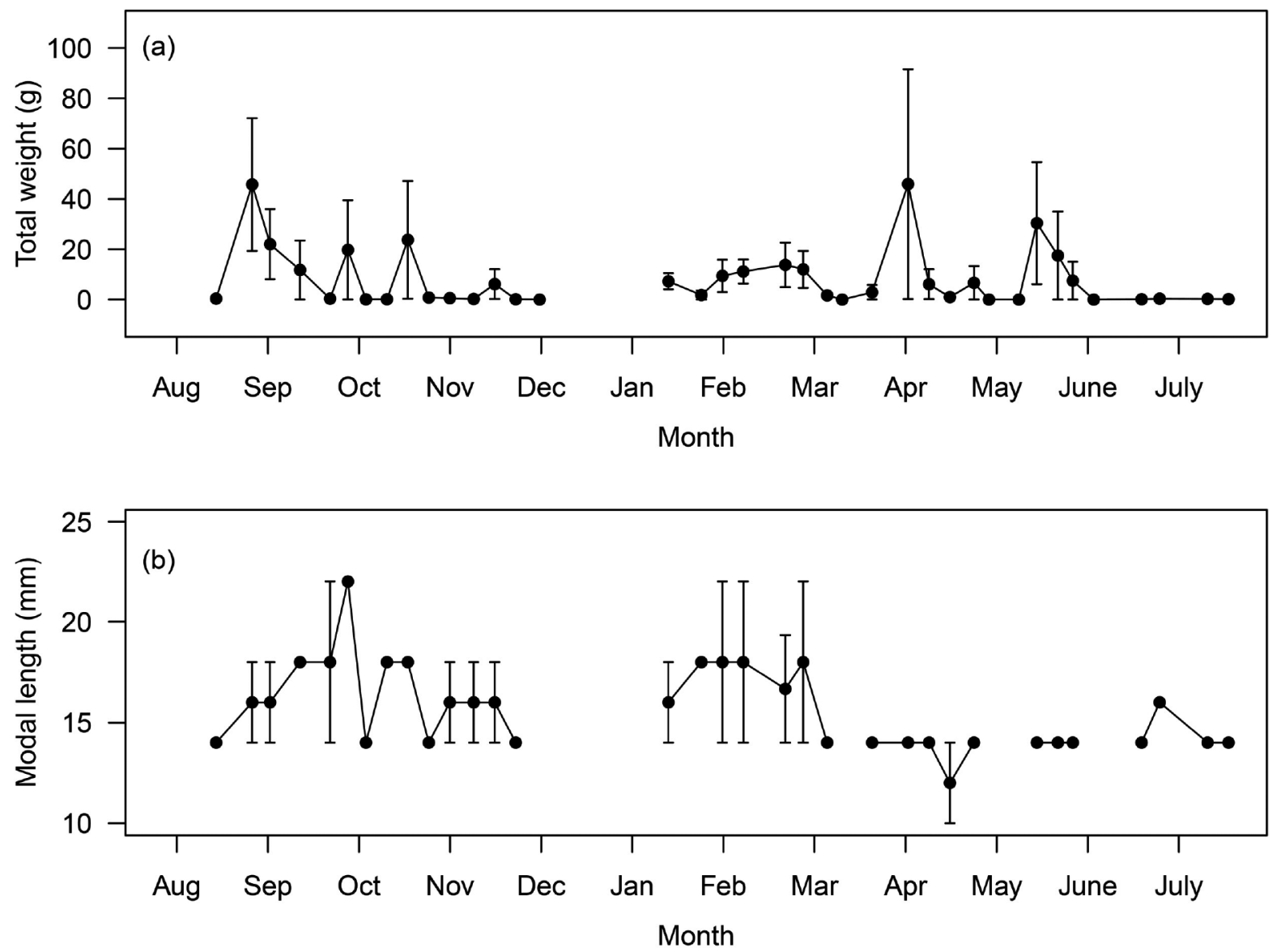

Supplementary Figure 2 - Seasonal changes in the weight $(\mathrm{g})$ of the total catch and the modal length $(\mathrm{mm})$ of Limnothrissa miodon larvae in the littoral samples between August 2009 and July 2010. Values represent the average of the captures at four different beaches. Vertical bars represent standard errors. This figure was reproduced from MuLIMBWA et al. (2014b), with a small correction for the weight of the total catch in February 2010. 